\title{
X-Ray Crystallographic and Theoretical Studies of an Anticonvulsant Enaminone: Methyl 4-(4'-Bromophenyl)amino-6-methyl-2- oxocyclohex-3-en-1-oate
}

\author{
I.O. Edafiogho a B.J. Denny ${ }^{a}$ C.H. Schwalbe ${ }^{b}$ P.R. Lowe ${ }^{b}$ \\ aFaculty of Pharmacy, Kuwait University, Safat, Kuwait; b Department of Pharmaceutical and Biological Sciences, \\ Aston University, Birmingham, United Kingdom
}

\section{Key Words}

Anticonvulsant enaminone $\cdot \mathrm{X}$-ray structure $\cdot \mathrm{Ab}$ initio quantum mechanics

\begin{abstract}
Objective: The aims of this study were to establish the structure of the potent anticonvulsant enaminone methyl 4-(4'-bromophenyl)amino-6-methyl-2-oxocyclohex-3-en1-oate (E139), and to determine the energetically preferred conformation of the molecule, which is responsible for the biological activity. Materials and Methods: The structure of the molecule was determined by X-ray crystallography. Theoretical ab initio calculations with different basis sets were used to compare the energies of the different enantiomers and to other structurally related compounds. Results: The X-ray crystal structure revealed two independent molecules of E139, both with absolute configuration $\mathrm{C} 11(S), \mathrm{C} 12(R)$, and their inverse. Ab initio calculations with the 6-31G, 3-21G and STO-3G basis sets confirmed that the $\mathrm{C} 11(S), \mathrm{C} 12(R)$ enantiomer with both substituents equatorial had the lowest energy. Compared to relevant crystal structures, the geometry of the theoretical structures shows a longer $\mathrm{C}-\mathrm{N}$ and shorter $\mathrm{C}=\mathrm{O}$ distance with more cyclohexene ring puckering in the isolated molecule. Conclusion: Based on a pharma-
\end{abstract}

cophoric model it is suggested that the enaminone system $\mathrm{HN}-\mathrm{C}=\mathrm{C}-\mathrm{C}=\mathrm{O}$ and the 4-bromophenyl group in E139 are necessary to confer anticonvulsant property that could lead to the design of new and improved anticonvulsant agents.

Copyright $@ 2003$ S. Karger AG, Basel

\section{Introduction}

Enaminones are a diverse group of compounds [1, 2] exhibiting a range of pharmacological effects includingcardiovascular [2], histaminergic [3], antimalarial [4], and anticonvulsant activities [5-8]. The enaminone methyl 4(4'-bromophenyl)amino-6-methyl-2-oxocyclohex-3-en-1oate (E139), which contains two chiral centres, has been shown to be a very potent anticonvulsant agent [7], but it is not known which of the four possible enantiomers are responsible for the activity of the compound. The aims of this study were to determine the three-dimensional structure of E139 by X-ray crystallography, to compare this structure with those calculated by ab initio quantum mechanics using different basis sets, and to attempt to predict the energetically preferred enantiomers. It is hoped that these results will help in the design of more potent anticonvulsant compounds.

\section{KARGER \\ Fax + 41613061234 \\ E-Mail karger@karger.ch \\ www.karger.com

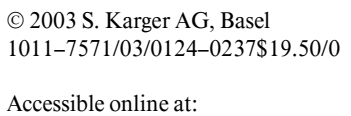

Dr. I.O. Edafiogho

Faculty of Pharmacy

Kuwait University, PO Box 24923

Safat 13110 (Kuwait)

Tel. +965 531 2300, Fax +965 534 2807, E-Mail ivanoe@hsc.kuniv.edu.kw 
Table 1. Crystal data and structure refinement for E139

\begin{tabular}{|c|c|c|}
\hline Identification code & \multicolumn{2}{|l|}{ e139babo } \\
\hline Empirical formula & \multicolumn{2}{|l|}{$\mathrm{C}_{30} \mathrm{H}_{32} \mathrm{Br}_{2} \mathrm{~N}_{2} \mathrm{O}_{6}$} \\
\hline Formula weight & \multicolumn{2}{|l|}{676.40} \\
\hline Temperature & \multicolumn{2}{|l|}{$293(2) \mathrm{K}$} \\
\hline Wavelength & \multicolumn{2}{|l|}{$0.71073 \AA$} \\
\hline Crystal system & \multicolumn{2}{|l|}{ orthorhombic } \\
\hline Space group & \multicolumn{2}{|l|}{ Pbca } \\
\hline \multirow[t]{3}{*}{ Unit cell dimensions } & $\mathrm{a}=8.8560(10) \AA$ & $\alpha=90 \mathrm{deg}$ \\
\hline & $\mathrm{b}=23.549(2) \AA$ & $\beta=90 \mathrm{deg}$ \\
\hline & $c=28.867(2) \AA$ & $\gamma=90 \mathrm{deg}$ \\
\hline Volume & \multicolumn{2}{|l|}{$6,020.2(9) \AA^{3}$} \\
\hline $\mathrm{Z}$ & \multicolumn{2}{|l|}{8} \\
\hline Density (calculated) & \multicolumn{2}{|l|}{$1.493 \mathrm{mg} / \mathrm{m}^{3}$} \\
\hline Absorption coefficient & \multicolumn{2}{|l|}{$2.737 \mathrm{~mm}^{-1}$} \\
\hline $\mathrm{F}(000)$ & \multicolumn{2}{|l|}{2,752} \\
\hline Crystal size & \multicolumn{2}{|c|}{$0.5 \times 0.4 \times 0.13 \mathrm{~mm}$} \\
\hline Theta range for data collection & \multicolumn{2}{|c|}{$2.23-24.98 \mathrm{deg}$} \\
\hline Index ranges & \multicolumn{2}{|c|}{$-4 \leq \mathrm{h} \leq 10,-27 \leq \mathrm{k} \leq 5,0 \leq 1 \leq 34$} \\
\hline Reflections collected & \multicolumn{2}{|c|}{5,845} \\
\hline Independent reflections & \multicolumn{2}{|c|}{$4,839[\mathrm{R}(\mathrm{int})=0.0705]$} \\
\hline Refinement method & \multicolumn{2}{|c|}{ full-matrix least-squares on $\mathrm{F}^{2}$} \\
\hline Data/restraints/parameters & \multicolumn{2}{|c|}{$4,839 / 8 / 365$} \\
\hline Goodness-of-fit on $\mathrm{F}^{2}$ & \multicolumn{2}{|c|}{0.853} \\
\hline Final $\mathrm{R}$ indices [I $>2 \operatorname{sigma}(\mathrm{I})]$ & \multicolumn{2}{|c|}{$\mathrm{R} 1=0.0667, \mathrm{wR} 2=0.1496$} \\
\hline $\mathrm{R}$ indices (all data) & \multicolumn{2}{|c|}{$\mathrm{R} 1=0.3489, \mathrm{wR} 2=0.2238$} \\
\hline Largest difference peak and hole & \multicolumn{2}{|c|}{0.457 and $-0.386 \mathrm{e} \cdot \mathrm{A}^{-3}$} \\
\hline
\end{tabular}

\section{Materials and Methods}

\section{Synthesis of E139}

The enaminone E139 was prepared and characterized according to the methods of Scott et al. [7].

Anticonvulsant Evaluation of E139

The anticonvulsant evaluation of E139 was carried out according to previously reported procedures [7].

\section{$X$-Ray Crystallography}

Repeated efforts at recrystallization of E139 yielded only weakly diffracting material. The best specimen was obtained from ethanol as a rectangular plate. Reflection data were measured by $\omega-2 \theta$ scans at rates as slow as $0.2 \mathrm{deg} \cdot \mathrm{min}^{-1}$ on an Enraf-Nonius CAD4 diffractometer equipped with a graphite monochromator using Mo $\mathrm{K} \alpha$ radiation $(\lambda=0.71073 \AA)$. The structures were solved by direct methods with the SHELXS program and refined with absorption corrections using SHELXL [9]. The features (approximately $0.5 \mathrm{e} \AA^{-3}$ or less) on a final difference Fourier map were not significant. Molecular illustrations were drawn with the ORTEP program [10]. Experimental details related to the structural analysis are provided in tables 1 and 2. Additional details of X-ray data are available upon request.

\section{Theoretical Studies}

$\mathrm{Ab}$ initio quantum mechanical self-consistent field geometry optimizations were carried out at the Hartree-Fock level without constraints using STO-3G, 3-21G and 6-31 G basis sets with gradient convergence criteria of $<0.001 \mathrm{Hartree} / \mathrm{Bohr}$ for the change in molecular energy as a function of the three-dimensional atomic displacement forces. All calculations were made with the ab initio package GAMESS [11] on a cluster of Intel-based IBM systems fitted with $650 \mathrm{MHz}$ CPUs. The compounds were visualized and geometry measurements were made with the molecular modelling package CHEM$\mathrm{X}[12]$ on an IBM machine.

\section{Results}

\section{Chemistry}

The enaminone E139 was obtained as a racemate with a melting point of $188-190^{\circ} \mathrm{C}$. Its UV data and elemental (CHNBr) analyses supported the assigned structure [7]. It has a molecular weight of 338.22 for the molecular formula $\mathrm{C}_{15} \mathrm{H}_{16} \mathrm{NO}_{3} \mathrm{Br}$, and a CLOGP value of 3.383. Proton NMR spectroscopy [8] supported the chemical structure of E139. The ${ }^{1} \mathrm{H}$ NMR data were $\delta \mathrm{CDCl}_{3} 1.07(3 \mathrm{H}, \mathrm{d}, \mathrm{J}=$ $\left.5.88 \mathrm{~Hz}, \mathrm{CH}_{3}\right), 2.20$ to $3.00(3 \mathrm{H}, \mathrm{m}$, cyclohexene ring), $3.06(1 \mathrm{H}, \mathrm{d}, \mathrm{J}=11.37 \mathrm{~Hz}$, cyclohexene ring), $3.72(3 \mathrm{H}, \mathrm{s}$, $\left.-\mathrm{OCH}_{3}\right), 5.46(1 \mathrm{H}, \mathrm{s},=\mathrm{CH}-), 6.97$ to $7.18\left(4 \mathrm{H}, \mathrm{m}, \mathrm{C}_{6} \mathrm{H}_{4}\right)$, 7.29 (1H, bs, $-\mathrm{NH}-)$. 
Table 2. Atomic co-ordinates $\left(\times 10^{4}\right)$ and equivalent isotropic displacement parameters $\left(\mathrm{A}^{2} \times 10^{3}\right)$ for e139babo

\begin{tabular}{|c|c|c|c|c|}
\hline & $\mathrm{x}$ & $\mathrm{y}$ & $\mathrm{z}$ & $\mathrm{U}(\mathrm{eq})$ \\
\hline $\operatorname{Br}(1)$ & $1,965(2)$ & $721(1)$ & $6,443(1)$ & $95(1)$ \\
\hline$C(1)$ & $2,398(14)$ & $367(6)$ & $5,876(4)$ & $55(4)$ \\
\hline$C(2)$ & $2,863(13)$ & $705(5)$ & $5,505(4)$ & $59(3)$ \\
\hline$C(3)$ & $3,124(13)$ & $464(5)$ & $5,082(4)$ & $54(3)$ \\
\hline $\mathrm{C}(4)$ & $2,898(14)$ & $-124(4)$ & $5,027(4)$ & $49(3)$ \\
\hline$C(5)$ & $2,566(14)$ & $-455(5)$ & $5,399(4)$ & $64(4)$ \\
\hline$C(6)$ & $2,274(13)$ & $-203(5)$ & $5,825(4)$ & $63(4)$ \\
\hline $\mathrm{N}(7)$ & $3,207(10)$ & $-388(3)$ & $4,588(3)$ & $50(3)$ \\
\hline $\mathrm{C}(8)$ & $2,772(13)$ & $-211(5)$ & $4,170(4)$ & $42(3)$ \\
\hline $\mathrm{C}(9)$ & $1,850(13)$ & $234(5)$ & $4,083(4)$ & $49(3)$ \\
\hline$C(10)$ & $1,472(14)$ & $400(5)$ & $3,639(4)$ & $55(4)$ \\
\hline$C(11)$ & $2,102(18)$ & $73(5)$ & $3,238(4)$ & $77(5)$ \\
\hline$C(12)$ & $3,367(19)$ & $-324(6)$ & $3,339(5)$ & $101(6)$ \\
\hline$C(13)$ & $3,280(15)$ & $-586(4)$ & $3,775(4)$ & 64(4) \\
\hline$C(14)$ & $2,395(17)$ & $442(6)$ & $2,848(6)$ & $100(7)$ \\
\hline $\mathrm{O}(15)$ & $3,300(13)$ & $842(5)$ & $2,891(4)$ & $120(4)$ \\
\hline $\mathrm{O}(16)$ & $1,747(15)$ & $382(5)$ & $2,478(4)$ & $154(6)$ \\
\hline$C(17)$ & $2,260(20)$ & $823(6)$ & $2,086(5)$ & $154(8)$ \\
\hline $\mathrm{O}(18)$ & $586(10)$ & 799(3) & $3,553(3)$ & $68(2)$ \\
\hline$C(19)$ & $3,826(16)$ & $-689(5)$ & $2,928(4)$ & $101(5)$ \\
\hline $\operatorname{Br}\left(1^{\prime}\right)$ & $9,439(2)$ & $1,917(1)$ & $6,911(1)$ & 111(1) \\
\hline$C\left(1^{\prime}\right)$ & $9,640(18)$ & $2,259(5)$ & $7,485(5)$ & $70(4)$ \\
\hline$C\left(2^{\prime}\right)$ & $10,584(18)$ & $2,711(5)$ & $7,564(5)$ & $81(4)$ \\
\hline$C\left(3^{\prime}\right)$ & $1,0691(15)$ & $2,945(5)$ & $7,988(5)$ & 71(4) \\
\hline$C\left(4^{\prime}\right)$ & $9,925(15)$ & $2,756(5)$ & $8,363(4)$ & $54(4)$ \\
\hline$C\left(5^{\prime}\right)$ & $8,931(15)$ & $2,299(5)$ & $8,294(5)$ & $71(4)$ \\
\hline$C\left(6^{\prime}\right)$ & $8,814(16)$ & $2,056(5)$ & $7,859(5)$ & $77(4)$ \\
\hline $\mathrm{N}\left(7^{\prime}\right)$ & $10,051(10)$ & $3,045(4)$ & $8,791(3)$ & $56(3)$ \\
\hline $\mathrm{C}\left(8^{\prime}\right)$ & $10,130(13)$ & $2,805(5)$ & $9,216(4)$ & $53(3)$ \\
\hline $\mathrm{C}\left(9^{\prime}\right)$ & $10,368(13)$ & $2,231(5)$ & $9,297(4)$ & $51(3)$ \\
\hline$C\left(10^{\prime}\right)$ & $10,341(14)$ & $2,008(5)$ & $9,734(4)$ & $57(3)$ \\
\hline$C\left(11^{\prime}\right)$ & $9,934(15)$ & $2,392(4)$ & $10,139(4)$ & $64(4)$ \\
\hline$C\left(12^{\prime}\right)$ & $10,152(18)$ & $2,974(5)$ & $10,067(4)$ & $87(5)$ \\
\hline $\mathrm{C}\left(13^{\prime}\right)$ & $9,952(13)$ & $3,204(4)$ & $9,612(4)$ & $59(4)$ \\
\hline$C\left(14^{\prime}\right)$ & $10,147(17)$ & $2,102(6)$ & $10,575(5)$ & $69(4)$ \\
\hline $\mathrm{O}\left(15^{\prime}\right)$ & $11,389(13)$ & $2,167(5)$ & $10,767(4)$ & $131(4)$ \\
\hline $\mathrm{O}\left(16^{\prime}\right)$ & $9,089(14)$ & $1,831(4)$ & $10,738(4)$ & $142(5)$ \\
\hline$C\left(17^{\prime}\right)$ & $9,660(20)$ & $1,531(6)$ & $11,213(4)$ & $148(8)$ \\
\hline $\mathrm{O}\left(18^{\prime}\right)$ & $10,686(9)$ & $1,500(3)$ & $9,828(3)$ & $69(2)$ \\
\hline $\mathrm{C}\left(19^{\prime}\right)$ & $9,669(14)$ & $3,378(4)$ & $10,463(4)$ & 73(4) \\
\hline
\end{tabular}
tensor.

$\mathrm{U}(\mathrm{eq})$ is defined as one third of the trace of the orthogonalized $\mathrm{U}_{\mathrm{ij}}$

\section{Pharmacology}

The enaminone E139 is a class 1 anticonvulsant in the maximal electroshock test [7]. It had an anticonvulsant activity in mice at a dose of $100 \mathrm{mg} / \mathrm{kg}$ intraperitoneally. It protected rats against seizures at an oral dose of $50 \mathrm{mg} /$ $\mathrm{kg}$ without causing any neurotoxicity for periods up to $4 \mathrm{~h}$.

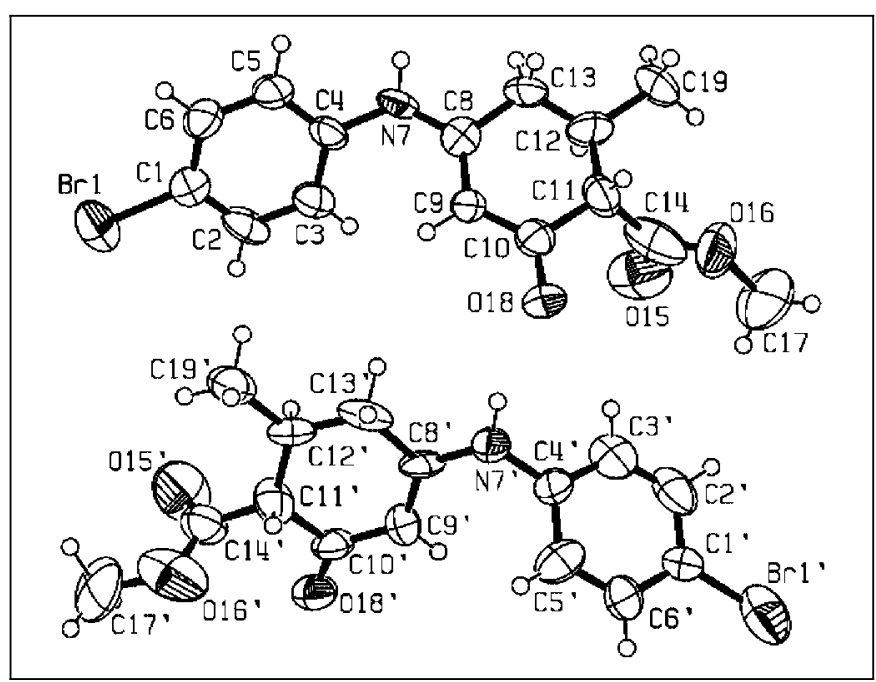

Fig. 1. ORTEP [16] drawing of E139. The primed molecule has been transformed by the $\mathrm{c}$ glide plane to show the hydrogen bond.

In the rat, E139 had a $\mathrm{TD}_{50}$ of $270 \mathrm{mg} / \mathrm{kg}$ and an $\mathrm{ED}_{50}$ of $4 \mathrm{mg} / \mathrm{kg}$ affording a protective index of $>67$. Thus, E139 is a potent anticonvulsant enaminone.

\section{X-Ray Crystal Structure of E139}

E139 crystallized from ethanol (table 1) showed two independent molecules (fig. 1). Chains were formed by hydrogen bonding between the $\mathrm{NH}$ and carbonyl oxygen (O18) groups of unprimed and primed molecules in succession. Therefore, the three-dimensional structure of E139 was determined by X-ray crystallography. The Xray data are listed in tables 1 and 2; table 2 gives the atomic co-ordinates and isotropic displacement parameters for non-hydrogen atoms.

\section{Theoretical Calculations}

The mean differences in heavy atom bond lengths, angles and torsions between the X-ray crystal structure and the theoretical structures calculated using different basis sets $(6-31 \mathrm{G}, 3-21 \mathrm{G}$ and STO-3G) are summarized in table 3 . The best agreement is with the theoretical structure calculated with the $3-21 \mathrm{G}$ basis set. Table 4 presents comparison of mean values of bond distances, bond angles, and torsion angles relevant to the enaminone and cyclohexene systems with those from the present crystal structure and from theoretical calculation. The theoretical structures show less delocalization in the enaminone moiety leading to more pronounced alternation of bond distances, and a more sharply puckered cyclohexene ring. 
Table 3. Mean differences between bond lengths, angles and torsion angles in crystal structure and theoretical structures (only non-hydrogen atoms in the molecule are considered)

\begin{tabular}{llll}
\hline & $6-31 \mathrm{G}$ & $3-21 \mathrm{G}$ & STO-3G \\
\hline Bond lengths, $\AA$ & 0.041 & 0.033 & 0.050 \\
Bond angles, degrees & 2.44 & 2.01 & 3.35 \\
Torsion angles, degrees & 7.42 & 6.43 & 7.55 \\
\hline
\end{tabular}

Table 4. Selected bond lengths, bond angles, torsion angles: comparison between average values in the crystal structure, average values in the CSD, and ab initio optimized structure

a Bond lengths $(\AA)$

\begin{tabular}{llll}
\hline & Crystal & CSD & $3-21 \mathrm{G}$ \\
\hline C4-N7 & 1.44 & 1.42 & 1.42 \\
N7-C8 & 1.33 & 1.35 & 1.37 \\
C8-C9 & 1.35 & 1.37 & 1.34 \\
C9-C10 & 1.38 & 1.43 & 1.45 \\
C10-O18 & 1.25 & 1.24 & 1.21 \\
\hline
\end{tabular}

b Bond angles $\left({ }^{\circ}\right)$

\begin{tabular}{llll}
\hline & $\begin{array}{l}\text { Crystal } \\
\left(\mathrm{SU}^{\circ}\right)\end{array}$ & $\begin{array}{l}\text { CSD } \\
\left(\mathrm{SSD} 1-2^{\circ}\right)\end{array}$ & $3-21 \mathrm{G}$ \\
\hline C4-N7-C8 & 127 & 127 & 128 \\
N7-C8-C9 & 126 & 124 & 125 \\
C8-C9-C10 & 123 & 122 & 123 \\
C9-C10-O18 & 123 & 122 & 123 \\
\hline
\end{tabular}

c Torsion angles $\left({ }^{\circ}\right)$

\begin{tabular}{lrrr}
\hline & Crystal & CSD & $3-21 G$ \\
\hline C4-N7-C8-C9 & $-5(2)$ & NM $^{1}$ & -5 \\
N7-C8-C9-C10 & $179(1)$ & 177 & 180 \\
N7-C8-C13-C12 & $-157,1$ & 157 & -161 \\
C8-C9-C10-C11 & 0,2 & 4 & 11 \\
C8-C9-C10-O18 & 178,1 & 177 & -170 \\
C9-C10-C11-C12 & $-14,2$ & 25 & -39 \\
C10-C11-C12-C13 & 34,2 & 48 & 56 \\
C11-C12-C13-C8 & $-41,2$ & 48 & -47 \\
C12-C13-C8-C9 & 28,2 & 25 & 21 \\
\hline
\end{tabular}

Standard uncertainties (SU) in the crystal structure and sample standard deviations (SSD) from the CSD are 0.01-0.02 $\AA$.

Because averaging is inappropriate, both independent molecules are given $\left(\mathrm{SU} 1-2^{\circ}\right)$. Since two different sequences of signs arise in the CSD, absolute values have been averaged (SSD from $2^{\circ}$ for N7C8-C9-C10 to $11^{\circ}$ for $\mathrm{C} 10-\mathrm{C} 11-\mathrm{C} 12-\mathrm{C} 13$ and $\mathrm{C} 11-\mathrm{C} 12-\mathrm{C} 13-\mathrm{C} 8$ ).

1 Not meaningful because values cluster around both $0^{\circ}$ and $180^{\circ}$.
Table 5. Energies (in $\mathrm{kJ} / \mathrm{mol}$ ) of the enantiomers of E139 relative to the most stable enantiomer calculated using different ab initio basis sets

\begin{tabular}{lrll}
\hline & $6-31 \mathrm{G}$ & $3-21 \mathrm{G}$ & STO-3G \\
\hline $\mathrm{C} 11(S), \mathrm{C} 12(R)$ & 0.00 & 0.00 & 0.00 \\
$\mathrm{C} 11(R), \mathrm{C} 12(R)$ & 5.02 & 3.34 & 1.73 \\
$\mathrm{C} 11(S), \mathrm{C} 12(S)$ & 11.79 & 8.47 & 5.77 \\
$\mathrm{C} 11(R), \mathrm{C} 12(S)$ & 8.82 & 4.60 & 4.27 \\
\hline
\end{tabular}

Atom numbering is taken from figure 1 (ORTEP drawing).

The relative energies of the different enantiomers of E139 optimized by different ab initio methods are given in table 5. The results indicate that the lowest energy enantiomer is the $\mathrm{C} 11(S), \mathrm{C} 12(R)$ form with substituents equatorial, as observed in the X-ray crystal structure. Other enantiomers were generated by interchanging a substituent and a hydrogen atom on $\mathrm{C} 11$ and/or $\mathrm{C} 12$, and thus have one or more axial substituents. The rank order of their energies is the same for all three basis sets used for the calculations.

The absolute configuration of the molecule is $\mathrm{C} 11(S)$, $\mathrm{C} 12(R)$ (atom numbering based on the ORTEP drawing); their centrosymmetric images are also present. The angles between phenyl and enaminone planes are $48.0(6)^{\circ}$ and $52.6(6)^{\circ}$, respectively, and bond lengths confirm that $\mathrm{N} 7$ is more closely integrated into the enaminone $\pi$ system. Every bond angle in the enaminone moiety is expanded above $120^{\circ}$ (table $4 \mathrm{~b}$ ). The cyclohexene ring occurs in a twisted half-chair shape with torsion angles in the ring differing by up to $24^{\circ}$, presumably due to crystal packing forces. An analogous structure with two very different degrees of puckering in the cyclohexene rings has previously been reported [13].

\section{Discussion}

\section{Theoretical Calculations}

Enaminones in the crystalline state are subject to distortions that do not affect the isolated molecule. Although electron donation from $\mathrm{N}$ to $\mathrm{O}$ atoms always shortens the $\mathrm{C}-\mathrm{N}$ bond and lengthens $\mathrm{C}=\mathrm{O}$, this effect is exaggerated by resonance-assisted hydrogen bonding [14]. Sometimes a cyclohexene ring is found in an almost ideal sofa conformation [15], but other reported structures differ greatly from it. A search of the Cambridge Structural Database 
(CSD) [16] with 3-(secondary amino)-cyclohex-2-ene-1one as the search group, no other fused ring, and $\mathrm{R}<0.1$ revealed 26 independent molecules.

The theoretical results shown are for gas phase calculations, and the energetic preference for enantiomer and conformation could change in solution. However, NMR evidence indicates that a single species is formed. This is consistent with work on other enaminones where a single enantiomer is formed about a chiral position on the cyclohexene ring [13].

\section{Structural Requirements for Anticonvulsant Activity of E139}

In the high field ${ }^{1} \mathrm{H}$ NMR spectrum, the amino tautomer was predominant, and no evidence for the imino tautomer was found. The vinyl proton at $\delta 5.46$ indicated that the double bond in the enaminone system was a $\mathrm{C}=\mathrm{C}$ of the amino tautomer, and not a $\mathrm{C}=\mathrm{N}$ of the imino tautomer. If the imino tautomer existed to any significant extent, one would observe the methylene $\left(\mathrm{CH}_{2}\right)$ protons about $\delta 2.50$, and the vinyl proton signal would be diminished. The amino tautomer [8] was confirmed by the Xray crystallography of E139.

Using the putative binding site theory proposed by Dimmock et al. [17] and utilized by Pandeya et al. [18] in postulating the interaction of anticonvulsant compounds at a specific binding site, it would appear that the enaminone E139 fits the criteria for a good lead compound. This theory proposes that anticonvulsant compounds interact at two locations at the binding site. These are designated the hydrogen bonding and the hydrophobic bonding areas. In the absence of an identified binding site, it was assumed that the hydrogen bonding area was a peptide chain whereby the repeating amidic functions allow hydrogen bond formation. We suggest that the pharmacophoric descriptors for E139 are the 4-bromophenyl group being complementary to the hydrophobic bonding area, and the enaminone system $\mathrm{HN}-\mathrm{C}=\mathrm{C}-\mathrm{C}=\mathrm{O}$ being complementary to the hydrogen bonding area (fig. 2). To achieve the suggested hydrogen bonding, the enaminone $\mathrm{C}=\mathrm{C}$ bond must be cis to the $\mathrm{N}-\mathrm{H}$ bond, not the $\mathrm{N}$-phenyl bond as in the crystal structure. Among other enaminone systems incorporating an anilino substituent, four crystal structures do exhibit the required cis relationship between $\mathrm{C}=\mathrm{C}$ and $\mathrm{N}-\mathrm{H}$.

The heteroconjugated enaminone system $\mathrm{HN}-\mathrm{C}=\mathrm{C}-$ $\mathrm{C}=\mathrm{O}$ in E139 would form resonance-assisted hydrogen bonds [14], and intermolecular bonds can give rise to infinite molecular chains called catemers. The cyclohexene ring holds the enaminone system in a fixed conforma-

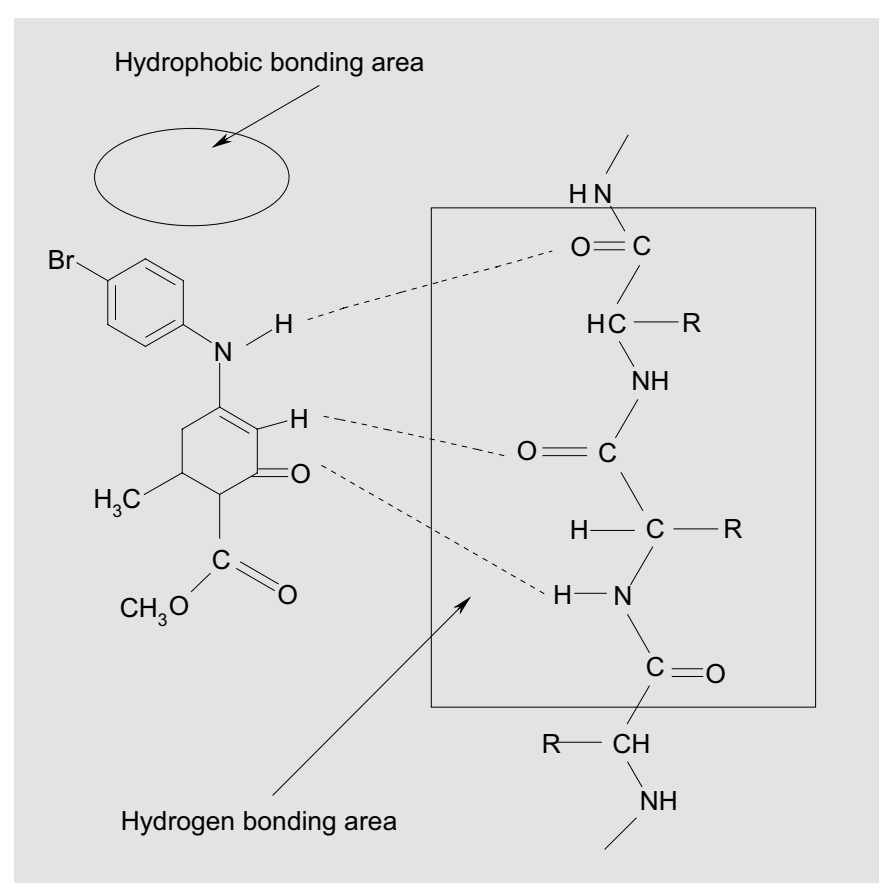

Fig. 2. Proposed interactions of enaminone E139 at a binding site [adapted from ref. 17].

tion, and theoretical ab initio calculations confirmed that the $\mathrm{C} 11(S), \mathrm{C} 12(R)$ enantiomer with both substituents equatorial had the lowest energy. The previously mentioned researchers have indicated that the 4-bromophenyl moiety fulfilled the structural requirements for binding at the hydrophobic binding site $[17,18]$. Similarly, the 4bromophenyl group and the enaminone system in E139 satisfy the structural requirements for interaction at a putative binding site for anticonvulsant compounds.

\section{Conclusion}

The E139 enaminone has been shown to have desirable anticonvulsant property. It is not neurotoxic in rats at an oral dose of $50 \mathrm{mg} / \mathrm{kg}$ and can be a lead compound for further molecular modification that will result in more potent anticonvulsant agents. 


\section{References}

1 Cholli AL, Lau ML, Gala K: Necessary conditions for the pi-electron delocalization of enamino-type muscle relaxants. J Pharm Sci 1993; 82:1275-1280.

2 Dannhardt G, Dominiak P, Laufer S: Hypertensive effects and structure-activity relationships of 5-omega-aminoalkyl isoxazoles. Arzneimittelforschung 1993;43:441-444.

3 Patzel M, Liebscher J: Ring transformation with bridged 1,3-dicarbonyl heteroanalogues, III: 5-(omega-aminoalkyl)-1,2,4-oxadiazoles by ring-transformations of 3-methylthio-2-aza-3propeniminium salts. Arch Pharm (Weinheim) 1991;324:963-965.

4 Dominguez JN, Lopez S, Charris J, Iarruso L, Lobo G, Semenov A, Olsen JE, Rosenthal PJ: Synthesis and antimalarial effects of phenothiazine inhibitors of a Plasmodium falciparum cysteine protease. J Med Chem 1997;40:27262732.

5 Edafiogho IO, Moore JA, Farrar VA, Nicholson JM, Scott KR: Synthesis, reactions and preliminary evaluations of enaminone esters. J Pharm Sci 1994;83:79-84.

6 Eddington ND, Cox DS, Roberts RR, Stables JP, Powell CB, Scott KR: Enaminones - versatile therapeutic pharmacophores: Further advances. Curr Med Chem 2000;7:417-436.
7 Scott KR, Edafiogho IO, Richardson EL, Farrar VA, Moore JA, Teitz EI, Hinko CN, Chang H, El-Assadi A, Nicholson JM: Synthesis and anticonvulsant activity of enaminones. 2. Further structure-activity correlations. J Med Chem 1993;36:1947-1955.

8 Edafiogho IO, Moore JA, Alexander MS, Scott KR: Nuclear magnetic resonance studies of anticonvulsant enaminones. J Pharm Sci 1994; 83:1155-1170.

9 Sheldrick GM: SHELXL, a Program for the Refinement of Crystal Structures. Göttingen, University of Göttingen, 1997.

10 Johnson CK: ORTEP. Report ORNL-5138. Oak Ridge, Oak Ridge National Laboratory, 1976.

11 Schmidt MW, Baldridge KK, Boatz JA, Elbert ST, Gordan MS, Jensen JH, Koseki S, Matsunaga N, Nguyen KA, Su SJ, Windus TL, Dupuis M, Montgomery JA: General atomic and molecular electronic-structure system. J Comput Chem 1993;14:1347-1363.

12 CHEM-X from Oxford Molecular Ltd, a subsidiary of Pharmacopoeia.
13 Foster JE, Nicholson JM, Butcher R, Stables JP, Edafiogho IO, Goodwin AM, Henson MC, Smith CA, Scott KR: Synthesis, characterization and anticonvulsant activity of enaminones. Part 6: Synthesis of substituted vinylic benzamides as potential anticonvulsants. Bioorg Med Chem 1999; 7:2415-2425.

14 Bertolasi V, Gilli P, Ferretti V, Gilli G: Intermolecular N-H...O hydrogen bonding assisted by resonance. II. Self-assembly of hydrogenbonded secondary enaminones in supramolecular catemers. Acta Crystallogr B 1998;54:50 65 .

15 Kubicki M, Codding PW: Methyl 4-(benzylamino)-6-methyl-2-oxo-3-cyclohexene-1-carboxylate, $\mathrm{C}_{16} \mathrm{H}_{19} \mathrm{NO}_{3}$. Acta Crystallogr C 1993;49: 2045-2046.

16 ConQuest from the Cambridge Crystallographic Data Centre, Cambridge, 2000.

17 Dimmock JR, Vashishtha SC, Stables JP: Anticonvulsant properties of various acetylhydrazones, oxamoylhydrazones and semicarbazones derived from aromatic and unsaturated carbonyl compounds. Eur J Med Chem 2000; 35:241-248.

18 Pandeya SN, Yogeeswari P, Stables JP: Synthesis and anticonvulsant activity of 4-bromophenyl substituted aryl semicarbazones. Eur J Med Chem 2000;35:879-886. 